This document has been downloaded from

TamPub - The Institutional Repository of University of Tampere

Post-print

The permanent address of the publication is http://urn.fi/URN:NBN:fi:uta-201411262346

Author(s): $\quad$ Kujala, Johanna; Toikka, Tiina; Heikkinen, Anna

Title: $\quad$ Communicating corporate responsibility through media

Year: $\quad 2009$

Journal Title: Progress in Industrial Ecology

Vol and number: $6: 4$

Pages: $\quad 404-420$

ISSN: $\quad$ 1478-8764

Discipline: $\quad$ Business and management

Item Type: Journal Article

Language: en

DOI: $\quad$ http://dx.doi.org/10.1504/PIE.2009.032327

URN: $\quad$ URN:NBN:fi:uta-201411262346

All material supplied via TamPub is protected by copyright and other intellectual property rights, and duplication or sale of all part of any of the repository collections is not permitted, except that material may be duplicated by you for your research use or educational purposes in electronic or print form. You must obtain permission for any other use. Electronic or print copies may not be offered, whether for sale or otherwise to anyone who is not an authorized user. 


\title{
Communicating Corporate Responsibility through Media
}

\author{
Johanna Kujala \\ Professor \\ Department of Management Studies \\ University of Tampere \\ FIN-33014 University of Tampere, Finland \\ johanna.kujala@uta.fi \\ Tiina Toikka \\ Researcher \\ Department of Management Studies \\ University of Tampere \\ FIN-33014 University of Tampere, Finland \\ tiina.toikka@uta.fi \\ Anna Heikkinen \\ Researcher \\ Department of Management Studies \\ University of Tampere \\ FIN-33014 University of Tampere, Finland \\ anna.heikkinen@uta.fi
}

\begin{abstract}
:
The purpose of this study is to analyse (1) how a company communicates its corporate responsibility activities through press releases and (2) how these activities are then presented by media in newspaper articles. Our analysis is targeted at an empirical case of building a pulp mill in Uruguay. The data consists of the company's press releases and of the newspaper articles published in the biggest quality daily in Finland related to the construction project. The data analysis is conducted as a qualitative content analysis. Corporate responsibility activities are identified utilising the three dimensions of corporate responsibility. In addition, the most important stakeholders are identified and the elements of firm-stakeholder relations analysed. Our findings suggest that in terms of the three dimensions of corporate responsibility the company provided more information than what the media presented to its audience. On the other hand, the newspaper articles consisted of much more information than the press releases regarding the stakeholder relationships.
\end{abstract}

Keywords: Corporate responsibility, Firm-stakeholder relationships, Media texts, Press releases, Conflict management, Stakeholder salience, Communication, Qualitative content analysis

Johanna Kujala is acting as professor of management and organization and director of the RESPMAN (Responsible Management) Research Group at the University of Tampere, Finland. Her dissertation from the University of Jyväskylä in 2001 dealt with Finnish managers' stakeholder perceptions and moral decision-making. Her articles have been published in Journal of Business Ethics, Business Ethics: A European Review, and International Journal of Value Based Management. She is a member of the review board of Business Ethics: A European Review. Her current research focuses on how stakeholder relations create value, multivoicedness in stakeholder strategizing, and on managers' moral decision-making. 


\section{INTRODUCTION}

Companies are nowadays expected to acknowledge their role in society, and to appreciate that they have a wide range of important stakeholders who ought to be taken into account in decision-making. Transparency and openness are seen as means to respond to the expectations of different stakeholders and to create trust (Clarkson, 1995; Crane and Livesey, 2003; Jones, 1995). Companies may use various information channels to publicise their practices to different audiences. Though companies nowadays engage increasingly in activities and communication directly with stakeholders, the media continues to be the main source of information regarding companies' operations and actions for the general public, and knowledge about companies' behaviour is often delivered through the media. Thus, it has been argued that the media have the power to decide which business issues will be covered and which not (Crane and Livesey, 2003). Especially in countries like Finland, where newspapers are widely distributed and read, the press has significant influence on the thoughts and opinions held by the general public.

There are several reasons for the media to work in various ways as a communication channel for business organisations. Press releases and other information received from companies serve as important material for journalists and, when there is a lack of resources in the editorial offices, materials published by organisations may be published as such (Juholin and Kuutti, 2003). However, media often has an active role in choosing and shaping the issues that will be published, and may assume the role of a gatekeeper since it has the option to report on about certain issues while ignoring others (Dearing and Rogers, 1996). With the help of media it is possible for an organisation to participate in public discussion and to influence its stakeholders.

Companies can set an agenda for news reports on corporate responsibility, but can never be sure what will or will not be published. It is possible that the targets and goals companies have imposed in their media releases are not achieved. The issue in question may never get any publicity, or the message may be reformulated in media so that its original content is lost. Besides the communicative objectives of the company in question, the form the message assumes in the media depends on the public's expectations of that media, on the commercial goals of the media corporation, as well as on the journalist's personal motives, preferences and methods (Richardson, 2007). Thus, the message the company wants to send may not reach the target group at least in its original form. The relationship may work in the opposite way as well: companies may include issues discussed in media in their reports and releases, for example, to reject the possible accusations or doubts voiced in media.

The purpose of this paper is to examine (1) how a company communicates its corporate responsibility activities through press releases and (2) how these activities are then presented in the media. To achieve this goal, we analyse both a company's press releases and newspaper articles related to an empirical case of building a pulp mill in Uruguay. We investigate the presentation of corporate responsibility issues and firm-stakeholder relations in these documents by asking what responsibility issues are covered, which stakeholders are the most important, and how relations with these stakeholders are presented.

Corporate responsibility is conceptualised in this paper through the notion of the triple bottom line where responsibility consists of three dimensions: financial, social and environmental (Carroll, 2004; Panapanaan et al., 2003; Steurer et al., 2005). In relation to financial responsibility, companies are expected to acknowledge the impact of business operations on society on a wider scale. Thus, financial responsibility is about taking into account and creating financial wellbeing for all stakeholders - not only the shareholders. The second dimension of corporate responsibility is social responsibility covering issues like human rights, equality in recruitment, employee wellbeing and creating social welfare in society. Environmental responsibility is the third dimension of corporate responsibility and includes 
issues like reducing the environmental impact of business operations, efficient use of natural resources and protecting the natural diversity.

Along with the three dimensions of corporate responsibility we pay attention to stakeholders and firm-stakeholder relations. The stakeholder approach has recently gained importance in the analysis of responsibility issues in business. The extensive body of literature on stakeholder theory presents the focal concept of a stakeholder which can be broadly defined as "any group or individual who can affect or is affected by the achievement of organisation's objectives" (Freeman 1984). Involving stakeholders in decision-making processes means that companies and stakeholders share information in a two-way communication process where both parties have a chance to express their views and opinions (Crane and Livesey, 2003). This kind of communication creates mutual trust and reliance, and leads to legitimacy for the business operations (cf. Grafé-Buckens and Hinton, 1998; Mikkilä, 2006). By continuous communication (Barney, 2003) and stakeholder inclusion (Wheeler and Sillanpää, 1997) a company can affirm and retain trust among its stakeholders.

Various researchers have pointed out that a typical classification approach to stakeholder management provides only a static view of the situation, although there is a need to understand the dynamic nature of stakeholder attributes (Aaltonen, Kujala and Oijala, 2008; Frooman, 1999; Mitchell, Agle and Wood, 1997). The critical relationships between an organisation and its stakeholders cannot be described as a simple transaction based on exchange between parties but they include co-operation, collaboration and network influences (Post, Preston and Sachs, 2002; Rowley, 1997). Thus, the focus should shift away from viewing stakeholders as separate from the focal organisation to actors whose relationships to the organisation constitute the organisation.

Empirically, we are interested in a case where Europe's second largest pulp producer, Metsä-Botnia (hereafter Botnia) invested in a pulp mill in South America, the city of Fray Bentos by the Uruguay River in western Uruguay. The investment has been considered remarkable because it, firstly, is the biggest foreign industrial investment a private Finnish company has ever made, and secondly, the pulp mill project is the biggest industrial investment in the history of Uruguay. The pulp mill is expected to benefit the state of Uruguay and its citizens financially, and Botnia has stated that the mill will have a considerable reflationary impact on the economy of the area as well as on the trade balance and national economy of the whole state of Uruguay. It was estimated that the mill would employ directly or indirectly approximately 8,000 people. (Botnia Annual Report, 2006)

Several reasons can be found for Botnia's decision to locate the mill in Uruguay. First, there was an increasing need for affordable raw material in Finland, the home country of the company, and the price of the eucalyptus pulp produced in Uruguay is only about one tenth of the cost of Finnish raw material (Stenberg, 2006). Moreover the eucalyptus tree also grows more rapidly than trees in Finland. Secondly, there is a general need among pulp producers to be located close to customers in order to serve them better and be cost-efficient. Thirdly, Uruguay is a good location as there is a well-defined regulation framework compared to the neighbouring federal countries of Brazil and Argentina, where local states have different tax and environmental laws. (Holtari, 2006)

Before the investment decision, the risks inherent in locating the mill next to the Uruguay River, which marks the border between Uruguay and Argentina, were assessed. A treaty signed by the two countries protects the use of the river, as it requires both parties to agree on any issue concerning the river. To its surprise, after the building process had started in 2005, Botnia was caught up in the middle of an intense debate between the two countries. Demonstrations and protests, such as road blocks on the bridge crossing the river, were organised by the Argentinean stakeholders to oppose the pulp mill. The opponents successfully used a wide variety of activities and tactics in order to increase their salience as perceived by the company thereby furthering their cause (Aaltonen, Kujala and Oijala, 2008). The opposition 
started because of environmental concerns related to the contamination of the river and thus, to the negative effect on revenues from tourism, although the environmental impact of the mill was minimised by taking advantage of the best available technology (Aaltonen, Kujala and Oijala, 2008). Initially, the dispute began as a disagreement between two nations. Soon, however, it was politicised into an open conflict between Uruguay and Argentina, as Argentina decided to take the case to the Hague International Court of Justice. The conflict burgeoned into a public issue, which attracted various sets of stakeholders, such as civic and environmental organisations, local people, workers, financiers, and the governments of Uruguay, Argentina and Finland. In late 2007, the mill went into production. Throughout the project, Botnia engaged in informing various stakeholders and the media, and the case also attracted considerable attention in the Finnish media. Thus, there is ample information available regarding the focus of our research.

\section{DATA COLLECTION AND ANALYSIS}

The data for our study was collected from two sources dealing with the building process of the Botnia pulp mill in Uruguay. First, Botnia's press releases related to the preparations, construction and start-up of the pulp mill were gathered from the company's website so that each release containing the word "Uruguay" in its heading or in the text was selected as part of the data. Second, the biggest quality daily in Finland, Helsingin Sanomat (hereafter HS) was chosen as a source of empirical media data. HS is prestigious and it serves as a respected voice in the public sphere, and it exerts both direct and indirect influence in Finnish society, since other newspapers and media use it as their source of ideas and information. This newspaper plays an important role in determining the importance of issues in society and politics in Finland. (Cf. Wiio, 2006) The quality, circulation, and level of influence of HS provide a good basis for analysing how the corporate responsibility activities are covered in the media.

Botnia's press releases were gathered from May 3, 2004 to November 29, 2007. This period was chosen because it comprehensively covers the main events related to the pulp mill project. As Table 1 shows, from 2004 two press releases were included in our data, from 2005, 2006 and 2007 there were 6,16 and 14 press releases included respectively. The proportion newspaper articles published in HS were limited to those from the same period and the search words used were "Botnia" and "Uruguay". Further, we excluded articles about appointments and other organisational issues and all editorials and letters to the editor. Altogether, 147 newspaper articles were included in our analysis, from 2004 there were no articles, from 2005, 2006 and 2007 there were 12, 89 and 46 articles (Table 1).

Table 1 Numbers of Botnia's press releases and articles published in Helsingin Sanomat May 2004 - December 2007

\begin{tabular}{|r|r|r|}
\hline \multirow{2}{*}{ Year } & $\begin{array}{r}\text { Botnia's press releases } \\
\text { n }\end{array}$ & $\begin{array}{r}\text { Articles published in HS } \\
\text { n }\end{array}$ \\
\hline 2004 & 2 & - \\
\hline 2005 & 6 & 12 \\
\hline 2006 & 16 & 89 \\
\hline 2007 & 14 & 46 \\
\hline Total & 38 & 147 \\
\hline
\end{tabular}

The data analysis was conducted as a qualitative content analysis (Eriksson and Kovalainen 2008; Graneheim and Lundman, 2004; Krippendorff, 2004) of the press releases and newspaper 
articles related to the pulp mill project. We started by analysing the content of the data according to the three dimensions of corporate social responsibility. First, we looked for financial, environmental or social issues in order to identify what kind of responsibility issues were communicated by the company, and how they were presented in the media. Our unit of analysis was single statements or expressions in the documents which we classified into three groups representing the financial, environmental or social dimensions of corporate responsibility. For example, a statement dealing with financiers and funding of the pulp mill project was classified as a financial issue, whereas environmental protection by purifying the effluent was classified as an environmental issue, and the participation of local people as a social issue. After having classified the statements in the press releases and the newspaper articles, we compared the results and found which issues were covered in both data sets.

We then proceeded to analyse issues related to stakeholders and firm-stakeholder relationships. First we identified the different actors (Bryman and Bell, 2007) mentioned in the data. These actors represented different stakeholders, including groups like local people, owners of the company, customers, and governments of Uruguay, Argentina and Finland as well as financiers. In order to ascertain which stakeholders were most frequently and extensively mentioned in the data, we calculated how often different stakeholders were mentioned in the press releases and in the newspaper articles (Table 2).

Table 2 Most frequently mentioned stakeholder groups

\begin{tabular}{|c|c|c|c|}
\hline & $\begin{array}{r}\text { Mentioned in } \\
\text { press releases } \\
\mathrm{n}\end{array}$ & $\begin{array}{r}\text { Mentioned in } \\
\text { newspaper articles } \\
\mathrm{n}\end{array}$ & $\begin{array}{r}\text { Total } \\
\mathrm{n}\end{array}$ \\
\hline Uruguayan government & 21 & 41 & 62 \\
\hline Local people & 6 & 56 & 62 \\
\hline Argentinian government & 5 & 42 & 47 \\
\hline Finnish government & - & 16 & 16 \\
\hline $\begin{array}{l}\text { Civic and environmental } \\
\text { organisations }\end{array}$ & - & 15 & 15 \\
\hline Financiers & 9 & - & 9 \\
\hline Workers & 8 & - & 8 \\
\hline
\end{tabular}

In the press releases, the Uruguayan government, financiers, workers, local people, and the Argentinian government were the five most often mentioned stakeholder groups. In the newspaper articles, Argentinian citizens, the Argentinian, Uruguayan, and Finnish governments, as well as civic and environmental organisations were mentioned most often. On the basis of this analysis, we evaluated that the Uruguayan government, Argentinean government, and local people were Botnia's three most important stakeholder groups in this case. We continued by further analysing relationships with these three stakeholder groups.

We based our analysis of firm-stakeholder relationships on two earlier categorisations. Mitchell, Agle and Wood (1997) presented a thorough discussion on the elements of stakeholder relationships and concluded that the salience of stakeholders should be based on three attributes: (1) power, (2) legitimacy, and (3) urgency. According to them, power is engaged in a relationship when one actor causes another one to do something that it would not have otherwise done. Legitimacy is a generalised perception or assumption that the actions are desirable, proper, or appropriate according to social norms, values, and beliefs. Urgency is the degree to which stakeholder claims call for immediate attention. These three elements have been frequently used in various stakeholder studies (Aaltonen, Kujala and Oijala, 2008; Co and Barro, 2009; Magness 2008; Neill and Stovall, 2005; Parent and Deephouse, 2007). Myllykangas (2009) presented six additional elements of stakeholder relationships: (1) history 
of the relationship, (2) objectives of the stakeholders, (3) interaction in the relationship, (4) information sharing in the relationship, (5) trust between stakeholders, and (6) the potential of stakeholders to learn.

In our analysis, we combined the two studies presented above, and, as a result, analysed Botnia's relationships to the Uruguayan and the Argentinian governments and to local people according to these nine different elements of the stakeholder relationship. Table 3 presents the nine elements of firm-stakeholder relationships along with the empirical research questions asked of the research data during the process of data analysis.

Table 3 Nine elements of firm-stakeholder relationships and the related empirical research questions

\begin{tabular}{|l|l|}
\hline Element & Empirical research question \\
\hline Power & Who is presented as having power? \\
& How is power used? \\
\hline Legitimacy & $\begin{array}{l}\text { Who are presented as legitimate stakeholders? } \\
\text { What are presented as legitimate actions? }\end{array}$ \\
\hline Urgency & $\begin{array}{l}\text { Who are presented as urgent stakeholders? } \\
\text { What are presented as urgent actions? }\end{array}$ \\
\hline History & $\begin{array}{l}\text { What is presented about the stakeholders' history? } \\
\text { What is presented about the history of firm- } \\
\text { stakeholder relationships? }\end{array}$ \\
\hline Objectives & $\begin{array}{l}\text { What objectives of stakeholders are presented? } \\
\text { Are the objectives in the relationship congruent or } \\
\text { conflicting? }\end{array}$ \\
\hline Interaction & $\begin{array}{l}\text { What kind of interaction is presented? } \\
\text { How is the interaction presented (formal/informal, } \\
\text { direct/indirect)? }\end{array}$ \\
\hline Information sharing & $\begin{array}{l}\text { What kinds of information sharing are presented? } \\
\text { How is information sharing presented } \\
\text { (reciprocal/continuous)? }\end{array}$ \\
\hline Potential to learn & What kind of learning is presented? \\
\hline Trust & $\begin{array}{l}\text { What kinds of actions create or demonstrate trust? } \\
\text { Is trust reciprocal? }\end{array}$ \\
\hline
\end{tabular}

The element of power in the relationships was analysed by asking who is presented as wielding power in the documents and how power is used in the relationships. Legitimacy was analysed by asking who are presented as legitimate stakeholders and what are presented as legitimate actions. Urgency was analysed similarly by asking who are presented as urgent stakeholders and what are presented as urgent actions. History of the relationship was analysed by examining what is presented about stakeholders' history in general and what is presented about the history of firm-stakeholder relationships. To analyse the objectives of the stakeholders we asked what objectives are presented and whether the objectives in the relationship are congruent or conflicting. Next, interaction was analysed by asking what kind of interaction is presented and by examining whether it was formal or informal, and direct or indirect. Regarding information sharing, we analysed what kinds of information sharing are presented and whether the involvement of actors was reciprocal. The analysis of stakeholders' potential to learn was conducted by examining what kind of learning is presented. Finally to study the element of trust in relationships we asked what kinds of actions create or demonstrate trust and whether trust was reciprocal. 


\subsection{Dimensions of responsibility}

All three dimensions of corporate responsibility, financial, environmental, and social, are covered both in the company's press releases and in the newspaper articles under scrutiny. The issues under each dimension relate to the events and progress of the project. In 2004, when the project was prepared, the data consisted of only two press releases concerning the results of the different impact studies conducted by the company in terms of the financial, environmental and social effects of the project. No newspaper articles were published about the case in 2004.

As the construction works started in 2005 , the diversity and intensity of issues increased in both sources of data and the same trend continued throughout the rest of the project. The press releases covered financial issues related to the Finnish and the Uruguayan economy, environmental issues concerning the use of best available technology (BAT) and environmental permit, as well as social issues in terms of impact on employment. The newspaper articles covered financial issues related to Finland and Uruguay, environmental issues in terms of the FSC-certification of the eucalyptus plantations, and social issues in terms of impact on employment. Hence, the responsibility issues presented in both sources of data covered the financial and social dimensions of corporate responsibility. The financial issues included those related to Finland such as the acquisition of machinery from Finland and the domestic content of the project. Financial issues related to Uruguay included the impacts on local forest owners and on the Uruguayan economy. Social responsibility dimension was present in terms of the impact on employment in Uruguay.

As the conflict escalated in 2006, new issues and actions were addressed in the data. Regarding the financial dimension, the results of the cumulative impact study (CIS) were presented in both data. The results of the study concurred with the earlier impact assessments and therefore confirmed the positive impacts on the economy and on employment. Regarding environmental issues, the results of the environmental impact assessment (EIA) conducted by the company in the preparatory stage were covered in both data. In terms of social issues, impact on employment was covered both in press releases and in newspaper articles. In 2006, the company was accused of corruption but it did not publish a press release on this issue, instead its position on ethical standards in operations was presented by the media. Botnia also placed announcements about its environmental standards in Argentinian newspapers in order to reach the Argentinean audience. This issue was reposted in the newspaper articles. In terms of environmental issues, the company declared its willingness to undertake the treatment of the domestic sewage of the city of Fray Bentos and to enhance the quality of the water in the River Uruguay. This issue was dealt with only in the company's press releases.

During the last year of the project in 2007, no major new corporate responsibility issues were presented as the company was preparing for the start-up which was hoped to remove the concerns of the opposing stakeholders. Among financial issues, the final price of the investment was covered in both data. In addition, press releases contained information about inspecting the entire mill before the start-up, and newspaper articles about the project's impact on the Uruguayan economy. In terms of environmental issues, the company's willingness to treat the domestic sewage of the city of Fray Bentos was presented in both data. In addition, press releases covered the use of best available technology and environmental standards of International Finance Corporation (IFC) and Botnia as well as surveillance displays. Newspaper articles also publicised landscaping projects. Regarding social issues, the impact on employment was emphasised in both data sets, whereas press releases presented the results of the socio-economic study and surveillance displays.

Table 4 summarises the results of our analysis on a yearly basis. The first column presents the year under study, the second identifies the corporate responsibility issues addressed in Botnia's press releases, and the third column presents those issues covered in the newspaper 
articles. The issues addressed in both data sets are given in italics.

Table 4 Corporate responsibility issues addressed in press releases and media texts May 2004 - December 2007

\begin{tabular}{|c|c|c|}
\hline Year & Press releases & Newspaper articles \\
\hline 2004 & $\begin{array}{l}\text { Financial: } \\
\text { Impact on the GDP, BAT } \\
\text { Environmental: } \\
\text { BAT, results of EIA } \\
\text { Social: } \\
\text { Results of SES, impact on employment }\end{array}$ & \\
\hline 2005 & $\begin{array}{l}\text { Financial: } \\
\text { Issues related to Finland, impact on } \\
\text { local forest owners, impact on the } \\
\text { economy of Uruguay, BAT } \\
\text { Environmental: } \\
\text { BAT, environmental permit } \\
\text { Social: } \\
\text { Impact on employment }\end{array}$ & $\begin{array}{l}\text { Financial: } \\
\text { Issues related to Finland, impact on } \\
\text { local forest owners, impact on the } \\
\text { economy of Uruguay } \\
\text { Environmental: } \\
\text { FSC-certification of the eucalyptus } \\
\text { plantations } \\
\text { Social: } \\
\text { Impact on employment }\end{array}$ \\
\hline 2006 & $\begin{array}{l}\text { Financial: } \\
\text { Results of CIS, impact on the economy, } \\
\text { impact on GDP } \\
\text { Environmental: } \\
\text { EIA, BAT, FSC-certification, treatment } \\
\text { of domestic sewage, enhancing the } \\
\text { quality of water in the river. } \\
\text { Social: } \\
\text { Impact on employment }\end{array}$ & $\begin{array}{l}\text { Financial: } \\
\text { Results of CIS, impacts on the economy, } \\
\text { impact on the turnover of the } \\
\text { corporation } \\
\text { Environmental: } \\
\text { EIA, international standards, } \\
\text { announcements in Argentinean } \\
\text { newspapers } \\
\text { Social: } \\
\text { Impact on employment, ethical } \\
\text { standards }\end{array}$ \\
\hline 2007 & $\begin{array}{l}\text { Financial: } \\
\text { Final price of the investment, the entire } \\
\text { mill is fully inspected prior to start-up } \\
\text { and complies with the standards set by } \\
\text { the IFC and Botnia, SES } \\
\text { Environmental: } \\
\text { Treatment of domestic sewage, BAT, } \\
\text { the standards of IFC and Botnia, audits } \\
\text { by DINAMA, surveillance displays } \\
\text { Social: } \\
\text { Impact on employment, SES, } \\
\text { surveillance displays }\end{array}$ & $\begin{array}{l}\text { Financial: } \\
\text { Final price of the investment, impact on } \\
\text { the Uruguayan economy } \\
\text { Environmental: Treatment of domestic } \\
\text { sewage, landscaping projects } \\
\text { Social: } \\
\text { Impact on employment }\end{array}$ \\
\hline $\begin{array}{l}\text { Abbre } \\
\text { BAT (1 } \\
\text { CIS (C } \\
\text { DINAI } \\
\text { EIA (E } \\
\text { FSC (F } \\
\text { GDP ( } \\
\text { IFC (Ir } \\
\text { SES (S }\end{array}$ & $\begin{array}{l}\text { lations: } \\
\text { est Available Technology) } \\
\text { Imulative Impact Study) } \\
\text { IA (Uruguay's Environment Ministry) } \\
\text { ivironmental Impact Assessment) } \\
\text { brest Stewardship Council) } \\
\text { ross domestic product) } \\
\text { ernational Finance Corporation) } \\
\text { cio-Economic Impact Study) }\end{array}$ & Italic $=$ issues presented in both data \\
\hline
\end{tabular}


As Table 4 shows, all three dimensions of corporate responsibility were covered throughout the whole research period in the press releases. The variety of issues and activities presented in the releases increased as the construction work on the pulp mill progressed. Issues related to environmental and social dimensions were clearly highlighted during the construction work in 2006 and 2007. The growing number of environmental actions can be seen as a response to the escalating conflict and growing stakeholder demands. Through the press releases the company could only reach a certain audience, however, and therefore the issues presented can be seen as reassurances by the company to the owners and financiers and also to the general public, to the extent that the media also presented the issues.

In the newspaper articles, all three dimensions of corporate responsibility issues were discussed throughout the media coverage, too. Financial issues were emphasised in the articles and other issues were typically presented in congruence with the statements and demands of the opposing stakeholders. In 2004, there were no newspaper articles covering the pulp mill project, even though the company had released information about its responsibility activities, such as the socio-economic impact study (SES) and the environmental impact assessment conducted by the company. It is also noteworthy that the media presented a few issues that were not mentioned in the press releases. These contained mostly information about financial responsibility issues and only very little information about social or environmental actions. However, in response to the corruption accusations in 2006 the company did not publish a press release, but its position on ethical standards in operations was presented by the media.

\subsection{Firm-stakeholder relations}

To further understand corporate responsibility activities in this case we analysed the case from the stakeholder viewpoint. We first defined who the stakeholders were in this case by identifying the stakeholders covered in the data and concluded that the Uruguayan government, the Argentinian government, and local people were the three most important stakeholder groups. We continued by further analysing firm-stakeholder relationships according to nine elements: (1) power, (2) legitimacy, and (3) urgency (Mitchell, Agle and Wood, 1997), (4) history of the relationship, (5) objectives of the stakeholders, (6) interaction in the relationship, (7) information sharing in the relationship, (8) trust between stakeholders, and (9) the potential of stakeholders to learn (Myllykangas, 2009). In the following, we present the results of our analysis on how corporate responsibility is presented in the data in terms of firm-stakeholder interaction.

\section{Relations with the Uruguayan government}

According to our two sources of data the relationship between Botnia and the Uruguayan government can be seen based on the pursuit of mutual benefit. Both parties had power to affect the other in this relationship. Botnia, for example, demonstrated its power to the Uruguayan government by pointing out the financial benefits the pulp mill would bring to Uruguay. The Uruguayan government, on the other hand, had the power to decide if the mill would receive the final environmental permit, and thus, if the mill could start up at all.

The Uruguayan government also had legitimate claims on the firm, when, for instance, it required Botnia to carry out an environmental impact assessment that is mandatory by law in Uruguay. The requests for the suspension of the installation works were even important to the Uruguayan government on a political level and thus, urgent.

The objectives of the Uruguayan government were to have the pulp mill started since it indicated its support for the project by, for example, granting Botnia free trade zone status. Information was shared by both parties throughout the entire project. The notable difference between the two sources of data was that the newspaper articles emphasised direct interaction 
and the formal nature of the relationship.

The elements of the history of the relationship, the potential of the government to learn and trust were not covered in the data, yet there may have been some trust between the parties and at least Botnia tried to create this by showing its willingness to share information and to support the efforts to solve the conflict between Uruguay and Argentina.

\section{Relations with the Argentinian government}

According to the analysis of the press releases and the newspaper articles, the relationship between Botnia and the Argentinian government mainly included indirect elements. The Argentinian government sought to influence the Uruguayan government to prevent and later to halt the construction work. In pursuing these objectives, the Argentinian government used its power.

The Argentinian government exerted its power through other parties, such as the World Bank and the Hague International Court of Justice. The claims to stop the project were based on the contract between the countries concerning the use of the River Uruguay, and could thus be seen as legitimate. The requests to suspend the installation work were important to the Argentinian government and thus, urgent.

The third element of the stakeholder relationship apparent in the releases was the objectives of the Argentinian government. It clearly wanted to prevent the construction of the pulp mill. The only example of having its effect on the actions of Botnia is that Botnia decided to suspend the installation works when requested. But it should be noted that the suspension was not requested jointly with the Uruguayan government. The other five elements of stakeholder relationships were not presented in the data.

\section{Relations with the local people}

The third stakeholder group that we included in our analysis consisted of the local people. This group includes both the citizens of Fray Bentos and of Gualeguaychú. In the press releases these groups were not separated, suggesting that Botnia treated these groups of people as one group. In the newspaper articles these two groups were separated, since their objectives and interests were disparate; the citizens of Fray Bentos supported the project due to its employment prospects, and the citizens of Gualeguaychú opposed it fearing environmental damage and the resulting negative effect on their tourism revenues. Both parties engaged in noticeable activities in order to further their respective causes; citizens of Fray Bentos organised demonstrations for the plant and citizens of Gualeguaychú organised demonstrations and road blocks to raise awareness of the effects of the project and to publicise its illegitimacy (cf. Aaltonen, Kujala and Oijala, 2008). On these grounds the claims of this stakeholder group can be deemed legitimate. Given the time sensitivity and crucial nature of these claims we categorise them as urgent.

According to our analysis Botnia had only little or no direct interaction with either group. The relationship between Botnia and the local people was built on sharing information. People in Fray Bentos were responsive, so the information sharing efforts paid off. Through these information sharing practices Botnia was trying to create trust in the relationship and, to some extent, it could be considered to have succeeded in Uruguay. However, the newspaper articles showed that the efforts at sharing information with the citizens of Gualeguaychú did not succeed.

\section{Summary}

The elements of the stakeholder relationships are summarised in Table 5. The nine dimensions are considered in relation to the three most important stakeholder groups in terms of whether they were present in press releases $(\mathrm{P})$ and/or newspaper articles $(\mathrm{A})$. 
Table 5 Elements of stakeholder relationships in relation to the three most important stakeholder groups RA20

\begin{tabular}{|l|c|c|c|}
\hline Element & $\begin{array}{c}\text { Uruguayan } \\
\text { government }\end{array}$ & $\begin{array}{c}\text { Argentinian } \\
\text { government }\end{array}$ & Local people \\
\hline Power & $\mathrm{P}$ & - & - \\
& $\mathrm{A}$ & $\mathrm{A}$ & - \\
\hline Legitimacy & $\mathrm{P}$ & $\mathrm{P}$ & - \\
& $\mathrm{A}$ & $\mathrm{A}$ & $\mathrm{A}$ \\
\hline Urgency & $\mathrm{P}$ & $\mathrm{P}$ & - \\
& $\mathrm{A}$ & $\mathrm{A}$ & $\mathrm{A}$ \\
\hline History & - & - & - \\
\hline Objectives & $\mathrm{P}$ & $\mathrm{P}$ & - \\
& $\mathrm{A}$ & $\mathrm{A}$ & $\mathrm{A}$ \\
\hline Interaction & $\mathrm{A}$ & - & - \\
\hline Information sharing & $\mathrm{P}$ & - & $\mathrm{P}$ \\
& $\mathrm{A}$ & - & $\mathrm{A}$ \\
\hline Potential to learn & - & - & - \\
\hline Trust & $\mathrm{P}$ & - & $\mathrm{P}$ \\
& $\mathrm{A}$ & - & $\mathrm{A}$ \\
\hline
\end{tabular}

$\mathrm{P}=$ press releases, $\mathrm{A}=$ newspaper articles

As Table 5 shows, the history of the relationship and stakeholders' potential to learn were not an important issue in this case. There are obvious similarities but also some differences in terms of which elements were emphasised in press releases and which in newspaper articles.

Regarding the relationship with the Uruguayan government, power, legitimacy and urgency in the relations as well as objectives of the relationship, information sharing and trust were emphasised both in press releases and newspaper articles. In addition, interaction between the company and the stakeholder was presented in the newspaper articles. In relations with the Argentinian government, legitimacy, urgency and interaction were emphasised in both data sources, whereas power was presented only in newspaper articles. In relations with the local people, only information sharing and trust were presented in both data sources, whereas legitimacy, urgency and objectives were presented only in the newspaper articles.

\section{DISCUSSION}

According to the results of our research it is evident that in this case the company provided more information about corporate responsibility in terms of financial, environmental and social issues than what the media conveyed to its audience. The media only reported a few issues in addition to those mentioned in the press releases.

On the other hand, the stakeholder analysis provides interesting insights into how the company and the media address corporate responsibility differently. In terms of firmstakeholder relations the newspaper articles contained much more information and the stakeholder relationships were described in more detail in the newspaper articles than in the press releases. Earlier research has found evidence that stakeholder identification is often incomplete due to managers' incomplete understanding of the situation (Parent and Deephouse, 2007). In the light of this case, it seems that stakeholder relations and their elements are more interesting to the media, too.

However, a surprisingly large number of dimensions in stakeholder relationships was presented similarly in both data sources. Maybe companies could and should trust the media more as a communication channel and provide more open and transparent information 
regarding their stakeholder relations. Although managers frequently fail to master the stakeholder interaction and companies are only partly in control of the firm-stakeholder relations (Roloff, 2008), they should try to improve their understanding and willingness to deal with stakeholder issues, which seem to be of more value to media than issues related to the financial, environmental and social dimensions of corporate responsibility.

The media aims at presenting issues that have news value, and in this case, the news value of the project increased as the conflict escalated. Therefore, it is not surprising that the media took a more profound interest in this case towards the end of the research period, and were active in presenting additional information about the project and the company. The media also presented the conflict and voices of opposing stakeholders surprisingly more thoroughly than the company in its press releases. This supports the idea that stakeholder relations are of interest to the media, and thus, companies should try to convert their issue based way of giving information into more relational language that caters better for the different actors involved in the case. Journalists write about cases like this no matter what and it is both a matter of business interest and a responsibility issue that they have the best possible information at hand when preparing articles for publication, also in terms of who are involved in the case and to whom the case is of interest. Although the company cannot set the agenda for news reporting on corporate responsibility, they can try to offer as much, as valid and as interesting information to the media as possible.

Our case gives insight into responsibility issues in conflict situations where the stakeholder groups that appear important may differ from the 'business as usual' situations. Although in this case the company seems to have taken care of its corporate responsibility issues beforehand, the conflict situation caused it to face a communication problem. Practices and procedures regarding corporate communication that appear adequate in normal circumstances are simply not enough when a conflict arises.

\section{Limitations and future research}

There are certain limitations to our study that need to be considered. First, corporate responsibility issues and their coverage was analysed in this paper in only one case. Studying two or several cases would give additional data, make comparative research possible, enhance the generalisability of the results as well as increase the understanding of the effects of different case contexts on corporate responsibility issues.

Second, the research was based on the analysis of only one Finnish newspaper. Including articles from newspapers published in Uruguay and Argentina might give more insight into the responsibility issues covered as well as to the most important stakeholders and the relationships in the global arena. Furthermore, to gain a deeper understanding of the case and the relationships, the secondary data used in this study could be supplemented by interviewing the parties to the conflict. This would enhance the credibility of the research.

The research conducted raises an interesting question as to why companies want to be responsible and communicate responsibility. Is it just because bad publicity is bad for business? Or is responsibility a way to stand out from the competitors? These questions are beyond the scope of this study but may serve as an interesting starting point for further research on communicating corporate responsibility.

\section{CONCLUSIONS}

Companies communicate their corporate responsibility and stakeholder activities formally through press releases. Media has a key role in representing these issues to the general public, as it is regarded as an important source of information regarding companies' operations and actions. The purpose of this study was to analyse (1) how a company communicates its 
corporate responsibility activities through press releases and (2) how these activities are then presented by media in newspaper articles.

The analysis was targeted at an empirical case of building a pulp mill in Uruguay. This developed into a heated debate between various parties and attracted extensive media coverage in Finland. The data consists of the company's press releases related to the construction of the pulp mill and of the newspaper articles published in the biggest quality daily in Finland related to the construction project. A total of 38 press releases and 147 newspaper articles were analysed by qualitative content analysis.

First, corporate responsibility was conceptualised by the triple bottom line, where responsibility is stated to consist of three dimensions: financial, social and environmental. Secondly, the stakeholder approach was used to guide the data analysis. The most important stakeholders were identified and relations with these stakeholders were analysed based on nine elements presented in earlier research.

The research results suggest that even though companies are willing to communicate corporate responsibility issues, the content of the press releases does not always cater for the interests of media. In this case, the company presented more information about the financial, social and environmental issues but less information about the issues regarding the firmstakeholder relationships than was published in the press. In the light of our study, the content of companies' press releases about corporate responsibility could be improved by including information on stakeholder relations of interest to the media and to the public at large. 


\section{References}

Aaltonen, K., Kujala, J., and Oijala, T. (2008) 'Stakeholder salience in global projects', International Journal of Project Management, Vol. 26, No. 5, pp.509-516.

Barney, I. (2003) 'Engaging Stakeholders Lessons from Orissa', The Journal of Corporate Citizenship, Vol. 10, pp.51-63.

Botnia Annual Report 2006. Lönnberg Print.

Bryman, A. and Bell, E. (2007) Business Research Methods. Second Edition, New York, NY: Oxford University Press.

Carroll, A. B. (2004) 'Managing ethically with global stakeholders: A present and future challenge', Academy of Management Executive, Vol. 18, No.2, pp.114-120.

Clarkson, M. B. E. (1995) 'A Stakeholder Framework for Analyzing and Evaluating Corporate Social Performance', Academy of Management Review, Vol. 20, No. 1, pp.92-117.

Co, H. C. and Barro, F. (2009) 'Stakeholder theory and dynamics in supply chain collaboration', International Journal of Operations \& Production Management, Vol. 29, No. 6, pp.591-611.

Crane, A. and Livesey, S. (2003) 'Are You Talking to Me? Stakeholder Communication and the Risks and Rewards of Dialogue', In: Andriof, J., Waddock, S., Husted, B. and Sutherland Rahman, S. (eds.), Unfolding Stakeholder Thinking 2: Relationships, Communication, Reporting and Performance, (pp.39-52), Sheffield: Greenleaf Publishing Limited.

Dearing, J. \& Rogers, E. (1996) Communication concepts 6: Agenda-Setting, Thousand Oaks,CA: Sage.

Eriksson, P. and Kovalainen, A. (2008) Qualitative Methods in Business Research, London: Sage.

Freeman, R. E. (1984) Strategic management a stakeholder approach, Pitman, Boston.

Frooman, J. (1999) 'Stakeholder Influence Strategies', Academy of Management Review, Vol. 24, No. 2, pp.191-205.

Grafé-Buckens, A. and Hinton, A.F. (1998) 'Engaging the Stakeholders: Corporate Views and Current Trends', Business Strategy and the Environment, Vol. 7, pp.124-133.

Graneheim, U. H. and Lundman, B. (2004) 'Qualitative Content Analysis in Nursing Research: Concepts, Procedures and Measures to Achieve Trustworthiness', Nurse Education Today, Vol. 24, pp.105-112.

Holtari, S. (2006) 'Sellumies törmäsi politiikkaan'(Pulp project collided with politics), Talouselämä 3.3.2006, pp.56-58. (In Finnish)

Jones, T. M. (1995) 'Instrumental Stakeholder Theory: a Synthesis of Ethics and Economics', Academy of Management Review, Vol. 20, No. 2, pp.404-437.

Juholin, E. and Kuutti, H. (2003) Mediapeli. Anatomia ja keinot, (Media game: The Anatomy and the Means), Helsinki: Inforviestintä Oy. (In Finnish)

Krippendorff, K. (2004) Content Analysis: An Introduction to Its Methodology. Thousand Oaks, CA: Sage Publications, Inc.

Magness, V. (2008) 'Who are the stakeholders now? An empirical examination of the Mitchell, Agle, and Wood theory of stakeholder salience', Journal of Business Ethics, Vol. 83, pp.177-192.

Mikkilä, M. (2006) The many faces of responsibility: Acceptability of the global pulp and paper industry in various societies, Dissertationes Forestales 25. Helsinki: Finnish Society of Forest Science.

Mitchell, R. K., Agle, B. R., and Wood, D. J. (1997) 'Toward a Theory of Stakeholder Identification and Salience: Defining the Principle of Who and What Really Counts', Academy of Management Review, Vol. 22, pp.853-889. 
Myllykangas, P. (2009). Sidosryhmäsuhteet liiketoiminnan arvon luomisessa - Palveluyksiköstä liiketoiminnaksi, episodi yrityksen elämää. (Value creation in stakeholder relationships From a corporate sub-division to an independent service company), $\mathrm{PhD}$ thesis. Tampere: University of Tampere. (In Finnish)

Neill, J. D. and Stovall, O. S. (2005) 'Stakeholder salience and corporate social responsibility: Evidence from three companies', Journal of Applied Business Research, Vol. 21, No. 3, pp.71-78.

Panapanaan, V. M., Linnanen, L., Karvonen, M-M., and Phan, V. T. (2003) 'Roadmapping Corporate Social Responsibility in Finnish Companies', Journal of Business Ethics, Vol. 44, pp.133-148.

Parent, M. and Deephouse, D. (2007) 'A case study of stakeholder identification and prioritization by managers', Journal of Business Ethics, Vol. 75, No. 1, pp.1-23.

Post, J. E., Preston, L. E., and Sachs, S. (2002) 'Managing the Extended Enterprise: The New Stakeholder View', California Management Review, Vol. 45, pp.6-28.

Richardson, J. E. (2007) Analysing newspapers: An approach from critical discourse analysis, Palgrave Macmillan: Basingstoke.

Roloff, J. (2008) 'Learning from Multi-Stakeholder Networks: Issue-Focused Stakeholder Management', Journal of Business Ethics, Vol. 82, pp.233-250.

Rowley, T. J. (1997) 'Moving Beyond Dyadic Ties: a Network Theory of Stakeholder Influences', Academy of Management Review, vol. 22, no. 4, pp.887-910.

Stenberg, E. (2006) 'Plant Location and Political Risk, Case Botnia Pulp Mill in Uruguay'. Paper presented at EIBA Annual Conference. December 7-9, 2006. Fribourg, Switzerland.

Steurer, R., Langer, M. E., Konrad, A. and Martinuzzi, A. (2005) 'Corporations, Stakeholders and Sustainable Development I: A Theoretical Exploration of Business-Society Relations', Journal of Business Ethics, Vol. 61, pp.263-281.

Wheeler, D. \& Sillanpää, M. (1997) The stakeholder corporation: A blueprint for maximizing stakeholder value, London: Pitman.

Wiio, J. (2006) Media uudistuvassa yhteiskunnassa. Median muuttuvat pelisäännöt. (Media in renewing society. The changing rules of the media), Sitran raportteja 65. Helsinki: Edita Prima Oy. (In Finnish) 